\title{
ALOKACJA I REDYSTRYBUCJA ZASOBÓW MIESZKANIOWYCH W POLSCE W KONTEKŚCIE KONCEPCJI SPRAWIEDLIWOŚCI SPOŁECZNEJ (RAWLSA I DWORKINA)
}

\section{WSTEPP}

Od momentu wprowadzenia programu „Rodzina na swoim” (2006) charakter prowadzonej polityki mieszkaniowej został rozszerzony o nowe obszary. Obok wsparcia gospodarstw domowych w pokrywaniu kosztów wynikających z użytkowania lokalu mieszkalnego i dostarczania na rynek mieszkań dostępnych cenowo, jednym z ważniejszych zadań polityki mieszkaniowej stało się wsparcie gospodarstw domowych w uzyskaniu mieszkania na własność. Głównym celem tak realizowanej polityki mieszkaniowej państwa jest w założeniu zwiększanie sprawiedliwości społecznej determinującej alokację i redystrybucję zasobu mieszkaniowego ${ }^{1}$.

Koncepcja sprawiedliwości społecznej ma w Polsce umocowanie w Konstytucji. W art. 2 ustawy zasadniczej stwierdza się, że Polska jest demokratycznym państwem prawnym, urzeczywistniajacym zasady sprawiedliwości społecznej². Zatem sprawiedliwość społeczna jest jedną z zasad ustrojowych. Stosowane w Konstytucji pojęcie sprawiedliwości społecznej można oprzeć na koncepcji sprawiedliwości dystrybutywnej zaproponowanej przez Johna Rawl$\mathrm{sa}^{3}$, kiedy to idea sprawiedliwości ma stanowić kryterium uzasadniania dystrybucji i alokacji zasobów mieszkaniowych.

W niniejszym artykule przeanalizowano ideę sprawiedliwości społecznej w kontekście reform polityki mieszkaniowej w latach 2006-2019. W tym celu dokonano krótkiego „przeglądu” najważniejszych odwołań filozoficznych, związanych ze sprawiedliwością społeczną (Platon, Arystoteles, Hume, Rousseau, Marks), w szczególności zaś - jako najistotniejszą bazę myślową do oceny „kondycji” sprawiedliwości w ramach polskiej polityki mieszkaniowej - omówiono

" Część informacji zawartych w artykule pochodzi z badań realizowanych przez dr Zuzannę Rataj w ramach projektu pt. „Społeczne budownictwo mieszkaniowe i jego rola w zaspokajaniu potrzeb mieszkaniowych niezamożnych gospodarstw domowych w Polsce" finansowanego ze środków Narodowego Centrum Nauki (2014/13/N/HS4/02100).

${ }^{1}$ Lis (2012): 205.

${ }^{2}$ Dz. U. 1997, Nr 78, poz. 483.

${ }^{3}$ Rawls (1994). 
koncepcję sprawiedliwości jako bezstronności Johna Rawlsa oraz jej specyficzne „wzmocnienie” w postaci krytyki Ronalda Dworkina. Najważniejsze pytania badawcze postawione na potrzeby tego artykułu to: (1) Czy pojęcie sprawiedliwości tkwi u podstaw ustalanych kryteriów, zasad polityki mieszkaniowej? (2) Jak to pojęcie jest rozumiane? (3) Jak jest „umocowana” koncepcja sprawiedliwości społecznej w polityce mieszkaniowej? (4) Który z proponowanych programów polityki mieszkaniowej podporządkowany jest normom sprawiedliwości dystrybutywnej Rawlsa, a który Dworkina?

\section{PRAWO DO MIESZKANIA JAKO FUNDAMENT SPRAWIEDLIWOŚCI SPOŁECZNEJ}

W Polsce prawo każdego obywatela do mieszkania reguluje art. 75 Konstytucji RP: „Władze publiczne prowadzą politykę sprzyjajacca zaspokojeniu potrzeb mieszkaniowych obywateli, w szczególności przeciwdziałaja bezdomności, wspierają rozwój budownictwa socjalnego oraz popieraja działania obywateli zmierzające do uzyskania własnego mieszkania"4, oraz ustawa z 21 czerwca 2001 r. o ochronie praw lokatorów, mieszkaniowym zasobie gminy i o zmianie Kodeksu cywilnego ${ }^{5}$, która wskazuje w art. 4, że: „tworzenie warunków do zaspokajania potrzeb mieszkaniowych wspólnoty samorządowej należy do zadań własnych gminy oraz, że gmina, na zasadach i w przypadkach określonych w ustawie, zapewnia lokale w ramach najmu socjalnego i lokale zamienne, a także zaspokaja potrzeby mieszkaniowe gospodarstw domowych o niskich dochodach".

Prawo do mieszkania znajduje również unormowanie w regulacjach światowych i europejskich. Dokumentami gwarantujacymi prawo do mieszkania sa:

- Powszechna deklaracja praw człowieka ONZ z 1948 r. ${ }^{6}$ - potwierdza prawo każdego człowieka do poziomu życia zapewniającego zdrowie i dobrobyt jemu i jego rodzinie, włączając w to wyżywienie, odzież, mies zka nie, opiekę lekarską i konieczne świadczenia socjalne;

- Międzynarodowy pakt praw gospodarczych, społecznych i kulturalnych z 1966 r. ${ }^{7}$ w art. 11 pkt 1. potwierdza prawo każdego człowieka i jego rodziny do odpowiedniego poziomu życia, włączając w to wyżywienie, odzież i mies zkanie, jak również prawo do stałej poprawy warunków egzystencji;

- Międzynarodowa konwencja o prawach dziecka z 1989 r. ${ }^{8}$ - art. 27 pkt 3 - zawiera wspólne zobowiązanie państw ratyfikujących do podejmowa-

${ }^{4}$ Dz. U. 1997, Nr 78, poz. 483.

${ }^{5}$ Dz. U. 2001, Nr 71, poz. 733.

${ }^{6}$ Zob. <https://amnesty.org.pl/wp-content/uploads/2016/04/Powszechna_Deklaracja_Praw_Czlowieka.pdf> [dostęp: 24.10.2019].

${ }^{7}$ Zob.<https://amnesty.org.pl/wp-content/uploads/2016/04/Miedzynarodowy-Pakt-Praw-gospspol-kult.pdf> [dostęp: 24.10.2019].

${ }^{8}$ Zob. <http://prawo.sejm.gov.pl/isap.nsf/download.xsp/WDU19911200526/T/D19910526L.pdf> [dostęp: 24.10.2019]. 
nia odpowiednich działań, aby pomóc rodzicom i osobom mającym na utrzymaniu dziecko przez wsparcie materialne i programy pomocowe, w szczególności w zakresie wyżywienia, odzieży i mieszkania;

- Deklaracja Światowej Konferencji ONZ Habitat II w Stambule z 1996 r. ${ }^{9}$ wskazuje, że „poszczególne kraje zobowiąują się do pełnej i postępujaccej realizacji prawa do odpowiedniego mieszkania, zgodnie z postanowieniami dokumentów międzynarodowych, oraz do zapewnienia równego dostępu do tanich i odpowiednich mieszkań wszystkim osobom i ich rodzinom”.

W Europejskiej karcie mieszkaniowej mieszkanie traktowane jest jako dobro pierwszej potrzeby, podstawowe prawo socjalne leżące u podstaw europejskiego modelu społecznego oraz element godności ludzkiej ${ }^{10}$. W akcie tym znajduje się również zapis, który kwalifikuje budownictwo społeczne do finansowania z funduszy strukturalnych, a także potwierdzajacy prawo do mieszkań o wysokiej jakości, w tym mieszkań socjalnych.

Europejska karta społeczna, podpisana w Strasburgu 3 maja 1995 r. ${ }^{11}$, zobowiązuje państwa sygnatariuszy do „popierania dostępu do mieszkań o odpowiednim standardzie; zapobiegania i ograniczania bezdomności, w celu jej stopniowego likwidowania; uczynienia kosztów mieszkań dostępnymi dla osób, które nie mają wystarczających zasobów”. Podkreśla się, że głównym warunkiem spójności społecznej i terytorialnej Unii Europejskiej jest dostęp do budownictwa mieszkaniowego, będącego jednym z głównych czynników walki z wykluczeniem społecznym i bezrobociem. Istotne wydaje się również podkreślenie przez Opinię Europejskiego Komitetu Ekonomiczno-Społecznego konieczności stworzenia zróżnicowanej oferty mieszkań, gdyż tylko taka umożliwi zapewnienie konkurencyjności wszystkich obszarów i ułatwi mobilność pracowników. Ponadto pomoc mieszkaniowa powinna uwzględniać specyficzne cechy mieszkalnictwa socjalnego, w tym słabą wypłacalność mieszkańców ${ }^{12}$.

\section{KONTEKST TEORETYCZNY: POJĘCIE SPRAWIEDLIWOŚCI JAKO PROBLEM BADAWCZY ORAZ TEORIE SPRAWIEDLIWOŚCI RAWLSA I DWORKINA}

Problematyka sprawiedliwości (oraz sprawiedliwości społecznej) w rozważaniach filozoficznych jest niezwykle złożona i wielowątkowa, ponieważ o pojęciu tym od starożytności mówi się w odniesieniu do innych, o charakterze moralno-wartościującym, pojęć. W tradycji kulturowej łączy się ją przede wszystkim z pojęciami dobra i trudu (multae tribulationes iustorum, ,sprawiedliwi muszą wiele wycierpieć”, Psalm 33,20), prawdy i wolności („La justice est la verité en action”, „Sprawiedliwość to prawda działająca”, J. Joubert,

\footnotetext{
9 Rataj (2018): 43.

10 Rataj (2018): 44.

11 Zob. <https://rm.coe.int/europejska-karta-spoleczna/16808b6383> [dostęp: 24.10.2019].

12 Zob. <https://www.prawo.pl/akty/dz-u-ue-c-2007-161-17,67695161.html> [dostęp: 24.10.2019].
} 
Myśli, 203), uczciwości i równości (,Gdyby nie była ręka, co by brała, wielka by zacność sprawiedliwość miała”, M. Rej, Apoftegmata, 2. Powieści o sprawiedliwości, 13-14) ${ }^{13}$. Jako pojęcie moralno-społeczne sprawiedliwość stanowi bardzo często centrum rozważań i ustaleń etycznych, funkcjonując jako punkt wyjścia opisu lub tworzenia norm, ustalających to, co określamy jako słuszne i dobre, oraz to, jak należy postępować, by spełniać ideał etyczny dobrego człowieka, i to zarówno w wymiarze jednostkowym, jak i społecznym. Warto również zaznaczyć, że ze względu na różnorodne dyscypliny, w ramach których mówi się o sprawiedliwości, pojęcie to egzystuje/ obowiązuje w dwóch głównych wymiarach - w „odsłonie” filozoficznej i „na terenie” prawa. W ramach pierwszego wymiaru ujmuje się je albo jako cnotę moralna, albo jako bazę (lub jej konstytutywną część) aksjologiczna; na gruncie prawa zaś funkcjonuje jako zasada, która jest/ ma być właściwością prawa czy instytucji (politycznych, społecznych).

Od starożytności do nowożytnego obywatelskiego państwa prawa pojęcie sprawiedliwości stanowiło problem badawczy, myślowy różnego (niekiedy nakładającego się) typu. Jako problem etyczny idea sprawiedliwości pojawia się w kontekście proponowanych systemów etycznych, w których funkcjonuje jako centrum wszelkich rozważań. Tak jest na przykład w Państwie Platona, kiedy to sprawiedliwość występuje zarówno jako cnota jednostki w koncepcji duszy, jak i jako cecha działalności władcy w koncepcji państwa ${ }^{14}$. Dzięki tej myśli Platona sprawiedliwość w odniesieniu do zamieszkiwania ujmuje się do dziś w dwóch głównych aspektach - czym jest ona dla jednostki, a czym dla systemu społecznego. Arystoteles w Etyce nikomachejskiej definiuje sprawiedliwość jako doskonałość etyczna, która objawia się w relacjach, stosunkach międzyludzkich (,sprawiedliwość jest identyczna z doskonałością etyczną [...] nie samą w sobie, w znaczeniu bezwzględnym, lecz w stosunkach z innymi ludźmi”'15) oraz wprowadza podział na sprawiedliwość rozdzielająca (,rozdzielanie zaszczytów lub pieniędzy, lub innych rzeczy, które mogą być przedmiotem rozdziału pomiędzy uczestników wspólnoty państwowej”16) i wyrównująca (wynikająca z z „rodzących zobowiązania” stosunków międzyludzkich; Stagiryta wyróżnia tu ponadto sprawiedliwość wyrównującą zależną od woli i od niej niezależna). Najem (mieszkania) jest przykładem sprawiedliwości wyrównującej zależnej od woli. W wymiarze politycznym idea sprawiedliwości rozważana jest w kontekście praktyki politycznej, zasad dystrybucji i egzekwowania władzy, jako problem prawny zaś odnosi się ją najczęściej do cech, własności określonych rozwiązań prawnych. Filozoficzne rozważania tej natury prowadził między innymi David Hume ${ }^{17}$, według którego idea sprawiedliwości ma swe źródło w egoizmie człowieka, ograniczonej życzliwości ludzi oraz braku rzeczy zaspokajających ich potrzeby (także mieszkaniowe) i funkcjonuje jako pewna umowa społeczna, konwencja dotycząca dystrybucji zasobów i zasad ich

\footnotetext{
13 Kopaliński (2003): 1217-1218.

14 Reale (1997): 291-300.

15 Arystoteles (1996): 169.

16 Arystoteles (1996): 172.

17 Hume (2005): 52.
} 
podziału, zależna od różnorodnych interesów. Inaczej ujmuje ten problem Jan Jakub Rousseau ${ }^{18}$, kiedy to rozważa ideę sprawiedliwości w kontekście idei równości - sprawiedliwe prawo ma znosić różnice między ludźmi, a wszyscy obywatele mają mieć równe uprawnienia. Na idei sprawiedliwości zbudowana jest również koncepcja nowych stosunków społecznych i stosunków produkcji zaproponowana przez Karola Marksa ${ }^{19}$, postuluje on uspołecznienie własności i oddanie każdemu według jego potrzeb.

Idea sprawiedliwości społecznej ujmowana jest w trojaki sposób. Po pierwsze - jako kryterium oceny stosunków społecznych; w odniesieniu do sprawiedliwości społecznej poddaje się więc ocenie panujący w danym społeczeństwie system stratyfikacji społecznej i „otwartość” społeczna.. Po drugie - traktuje się ją jako pewną zasadę, wzorzec, ideał, do którego społeczeństwo we wszystkich zakresach swego funkcjonowania „powinno dążyć”. Po trzecie - idea sprawiedliwości społecznej traktowana jest jako swoistego rodzaju przeniesienie humanistyczno-prawnej idei w sferę stosunków polityczno-gospodarczych. Określając sprawiedliwość społeczną jako cechę stosunków społecznych, a więc sposób traktowania określonych grup ze względu na ich przynależność do klas, narodów, warstw, płci, ras, wspólnot religijnych, ideologicznych (równoprawność, podział dóbr, władzy, prestiżu), wyróżnia się sprawiedliwość redystrybutywną i dystrybutywna. Sprawiedliwość redystrybutywna to przyznawanie według zasady równym za równe (występuje tu więc założenie o równowartości dóbr, wkładu pracy, niezależne od indywidualnego różnicowania, możliwości, uzdolnień), kompensowanie braków, działanie według zasady „więcej biednym, mniej bogatym”. W przypadku sprawiedliwości dystrybutywnej rozdział dóbr, świadczeń zależeć ma od oceny znaczenia, niezbędności i wkładu pracy, jak pisał Arystoteles - ma być to rozdział według cnót.

Koncepcją sprawiedliwości, która w szczególny sposób nawiazała do powyższych rozróżnień i po dziś dzień stanowi filozoficzny (a niekiedy nawet ideologiczny) punkt wyjścia rozważań na temat podstaw aksjologicznych współczesnych społeczeństw, kiedy to jednostki, grupy, społeczeństwa, ludzkość poddawane sa zmianom cywilizacyjnym, cyfryzacji, technologizacji, globalizacji, „płynności”, jest zaproponowana przez Rawlsa koncepcja sprawiedliwości jako bezstronności ${ }^{20}$. Kulturowym kontekstem powstania tej koncepcji były zmiany społeczne, które nastapiły wraz z ukonstytuowaniem się nowoczesnego społeczeństwa. Pojawiła się pewna pustka narracyjna wraz z „upadkiem” przedoświeceniowych przekonań o „naturalności” władzy, która sankcjonuje nierówności społeczne, usprawiedliwiając je naturalną hierarchią bytów. Co więcej - nastapił proces rozwoju kapitalizmu, opartego na industralizmie, który spowodował upowszechnienie się przekonań o coraz większej polaryzacji klasowej i konieczności zmiany niewystarczających już dotychczasowych instytucjonalnych rozwiązań polityczno-ekonomiczno-społecznych ${ }^{21}$. Swoista

\footnotetext{
18 Rousseau (1956): 321-368.

19 Marks (2010): 821-823.

20 Rawls (1994): 34-35, 55, 107-110, 160-170.

${ }^{21}$ Karalus (2015): 220-221.
} 
heglowska „sową Minewry, która wylatuje o zmierzchu”, stała się koncepcja Rawlsa, w ramach której pojęcie sprawiedliwości dystrybutywnej, czyli znalezienie uzasadnienia powszechnie podzielanych reguł rozdzielania społecznie wytworzonych dóbr, zogniskowało w sobie te dwa procesy. Punktem wyjścia koncepcji Rawlsa jest eksperyment myślowy, polegający na zbudowaniu umowy społecznej przy zastosowaniu tzw. kantowskiej zasłony niewiedzy. Polega to na wykorzystaniu idei myślenia transcendentalnego, to jest przekraczającego poznanie, zaprezentowanej przez filozofa z Królewca w Krytyce czystego rozumu. Kant - jak wiadomo - wykorzystał tego typu myślenie do postawienia pytań o warunki, ramy, które umożliwiają i są obecne w poznaniu (i zadania pytania, czy istnieją sądy syntetyczne a priori). Na tej podstawie dokonał przewrotu kopernikańskiego w epistemologii - to umysł, wyposażony w dwie formy naoczności (czas i przestrzeń) oraz 12 kategorii intelektu, aktywnie poznaje rzeczywistość, a nie rzeczywistość „odbija się” w umyśle. Dla Rawlsa każdy z nas, jako ludzi, jest uwarunkowany społecznie-kulturowo; w określony sposób (przez wiek, płeć, rasę, miejsce w stratyfikacji społecznej, zdrowie, wykształcenie, urodę itd.) postrzega rzeczywistość społeczną i w tym sensie zawsze jest jakaśs „stroną” (relacji, stosunków, hierarchii, konfliktu). Czymś, co umożliwia zmianę tego typu „stronniczego” myślenia jest „wbicie się” w myślenie transcendentalne, czyli oderwanie się od uwarunkowań tu-i-teraz i postawienie sobie pytań o charakterze krytycznym, uwzględniających wszelkie możliwe (re)kombinacje stosunków i relacji społecznych i ich uwarunkowania. Myślimy w ten sposób, kiedy „zasłonimy” się kotarą niewiedzy, to znaczy zaczniemy myśleć o zasadach, podstawach społecznych, zanim dowiemy się, kim w danym społeczeństwie jesteśmy. Zdaniem Rawlsa tego typu eksperyment myślowy - ustalmy zasady społeczne jako „bezstronne” jednostki, jako jednostki, które jeszcze nie wiedza, kim w społeczeństwie są i jakie „wyposażenie” społeczne reprezentują - doprowadzi nas do koncepcji sprawiedliwości jako bezstronności, która amerykański filozof wyraził w dwóch zasadach sprawiedliwości. Według pierwszej: „Każda osoba ma równe roszczenie do w pełni odpowiedniego systemu podstawowych praw i swobód, który system jest zgodny z tym samym systemem dla wszystkich; w tym systemie należy zagwarantować równe swobody polityczne, równość w godności”. Zgodnie z druga zasadą: „Nierówności społeczne i gospodarcze mają spełniać dwa warunki: po pierwsze, należy je dołączyć do stanowisk i sfer otwartych dla wszystkich w warunkach uczciwej równości szans; a po drugie, mają one być z największą korzyścią dla najmniej uprzywilejowanych członków społeczeństwa”. Pierwsza zasada dotyczy więc zapewnienia równego poziomu wolności dla wszystkich członków społeczeństwa, niezależnie od zajmowanej w nim pozycji. Druga reguła dotyczy nierówności społecznych i ekonomicznych - godne utrzymania są tylko te, które są korzystne dla wszystkich. Można więc powiedzieć, że Rawls (jak i Kant w przypadku imperatywu kategorycznego) „wierzy” w człowieka, to znaczy żywi przeświadczenie, że jako istoty ludzkie „wiemy”, jak powinien być zbudowany system społeczny, i tylko „zabrudzenie” danym wyposażeniem, jakie mamy jako określone jednostki, przeszkadza w sformułowaniu tych zasad. 
Ciekawym poznawczo uzupełnieniem koncepcji Rawlsa jest modyfikacja zasłony niewiedzy zaproponowana przez Dworkina w jego teście zawiści ${ }^{22}$. Zasłona jest półprzezroczysta, to znaczy pozwala na świadomość własnych predyspozycji i preferencji (życiowych) w hipotetycznej sytuacji alokacji zasobów przez aukcję, w której każdy posiada jednakową siłę nabywczą. Zakończenie aukcji ma nastapić w tym momencie, kiedy wszyscy jej uczestnicy pozytywnie „przejda” test zawiści (envy test), to znaczy nie będą zazdrościli innym koszyka wylicytowanych zasobów. Sprawiedliwość w ujęciu Dworkina „uzupełniona” jest więc o indywidualne zasługi, podejmowany wysiłek i odpowiedzialność jednostek za dokonane wybory. Dworkin dokonuje w swym projekcie krytyki egalitaryzmu Rawlsa, podkreślając, że sprawiedliwość powinna łączyć się nie tylko z wyrównywaniem szans, ale także brać pod uwagę indywidualne zaangażowanie jednostek ludzkich w życie.

Przedstawione powyżej omówienie pojęcia sprawiedliwości społecznej jako problemu badawczego w kontekście mieszkalnictwa (wskazujacce na konstytutywny i aksjologicznie bazowy charakter potrzeby zamieszkiwania zarówno w kontekście kondycji jednostki, jak i społeczeństwa) oraz koncepcji sprawiedliwości stworzonej przez Rawlsa, uzupełnionej o krytykę Dworkina, stanowi bazę wydzielania przez nas kryterium oceny realizacji idei sprawiedliwości w programach mieszkaniowych. O umocowywaniu sprawiedliwości dystrybutywnej w wersji egalitarnej, opartej na koncepcji Rawlsa, będzie można mówić w kontekście tych programów mieszkaniowych, które w swoich podstawach aksjologicznych „nakierowane” sa na bezstronne wyrównywanie szans w dostępie do mieszkań, natomiast o sprawiedliwości dystrybutywnej nieegalitarnej, w „duchu” koncepcji Dworkina, w odniesieniu do programów mieszkaniowych, w których bierze się uwagę określone interesy, roszczenia i zaangażowanie celowych grup społecznych.

\section{DOSTĘP DO MIESZKAŃ W KONTEKŚCIE SPRAWIEDLIWOŚCI DYSTRYBUTYWNEJ EGALITARNEJ I NIEEGALITARNEJ}

Analiza funkcjonujących w Polsce w latach 2006-2019 programów mieszkaniowych (tabela 1) pozwala zauważyć, że zaszły w nich istotne zmiany. Najważniejsze, z punktu widzenia niezamożnych gospodarstw domowych, które maja najbardziej ograniczone możliwości zaspokojenia potrzeb mieszkaniowych, dotyczą nowelizacji ustawy o ochronie praw lokatorów [Dz. U. 2018, poz. 1234]. Znowelizowana ustawa wprowadziła w miejsce mieszkań socjalnych i lokali najmowanych na czas nieoznaczony najem socjalny i najem z mieszkaniowego zasobu gminy. Mimo że kryteria dostępu do tych mieszkań pozostały bez większych zmian, istotne jest to, że gminy moga przeznaczyć na określony rodzaj najmu każde mieszkanie pochodzące z jej zasobu. Powoduje to, że nie ma określonej puli mieszkań socjalnych (o obniżonym standardzie) czy najmowanych

${ }^{22}$ Dworkin (2000): 11-120. 
na czas nieoznaczony, a gmina może przeznaczać swój zasób odpowiadając na realne potrzeby mieszkańców. Ponadto wprowadzenie kontroli dochodów w lokalach wynajmowanych przed nowelizacją na czas nieoznaczony umożliwia uwolnienie i rotację zasobu wśród gospodarstw, które mają niezaspokojone potrzeby mieszkaniowe i spełniają pozostałe kryteria uprawniające do podpisania umowy najmu lokalu mieszkalnego.

Kolejnym programem adresowanym do niezamożnych gospodarstw domowych są dodatki mieszkaniowe. Aby otrzymać taki dodatek, należy spełnić kryterium dochodowe i metrażowe. Dodatek wypłacany jest w postaci dopłaty do czynszu na okres sześciu miesięcy. Zadaniem dodatku mieszkaniowego jest wyrównywanie szans na regularne i terminowe opłacanie należności za użytkowanie lokalu mieszkalnego, a więc zwiększanie sprawiedliwości pionowej.

Mieszkania z zasobów Towarzystw Budownictwa Społecznego powszechnie nie są uznawane za rodzaj pomocy mieszkaniowej, gdyż aby „wejść” do zasobu, należy spełnić określone kryteria dochodowe, a także wpłacić 30\% partycypacji (w zależności od TBS, zazwyczaj jest to około $40000 \mathrm{zł}$ ) oraz kaucję. Z najmu wykluczone są zatem gospodarstwa domowe nieposiadajace odpowiedniej wysokości wkładu własnego. Ponadto dochody użytkowników lokali TBS-owskich nie moga „przekraczać przeciętnego miesięcznego wynagrodzenia w województwach [...] w pierwszym i trzecim kwartale danego roku" [www.tbs24.pl]. Dla poszczególnych gospodarstw dochody nie moga przekraczać 1,3 przeciętnego miesięcznego wynagrodzenia więcej niż o: 20\% w jednoosobowym gospodarstwie domowym, 80\% - w dwuosobowym gospodarstwie domowym, dalsze 40\% na każdą dodatkową osobę w gospodarstwie domowym z większą liczbą osób. Ustawa o niektórych formach popierania budownictwa mieszkaniowego nie definiuje minimalnych dochodów, ale Bank Gospodarstwa Krajowego zalecał TBS ustalenie także dolnych limitów dochodów w gospodarstwach domowych - np. w wysokości 50\% kwoty maksimum ustawowego. W trakcie działalności TBS niektóre zasady uległy znacznym modyfikacjom, częściowo wypaczając pierwotną ideę działalności spółek, zapewniających stabilny i długoterminowy najem. Coraz częściej pojawiają się w TBS opcje najmu mieszkań z dojściem do własności, co powoduje wyższy czynsz, w którym spłacany jest dany lokal mieszkalny. Powoduje to ubytek zasobu mieszkaniowego przeznaczonego na najem.

Najnowszy program wspierajacy obywateli w zaspokojeniu potrzeb mieszkaniowych Mieszkanie Plus wydaje się programem przełomowym, w szczególności z punktu widzenia sprawiedliwości społecznej. Jak zakładają twórcy programu, ma on być powszechny, adresowany do wszystkich grup społecznych. Mieszkanie Plus ma za zadanie wspierać ludzi, dla których uzyskanie własnego mieszkania było z różnych powodów niemożliwe. W przypadku większej liczby zainteresowanych skorzystaniem programu przewidziane sa dodatkowe kryteria umożliwiające alokację ograniczonego zasobu, takie jak liczba dzieci, struktura gospodarstwa domowego, aktualne potrzeby i poziom dochodów. Głównym kryterium jest jednak brak prawa własności do innego lokalu mieszkalnego i możliwość regularnego opłacania czynszu za mieszkanie. 


\begin{tabular}{|c|c|c|c|}
\hline \multirow{8}{*}{ 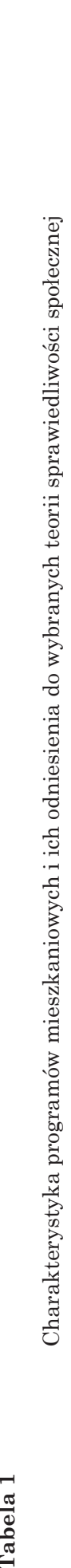 } & 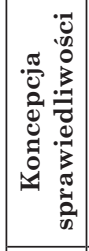 & 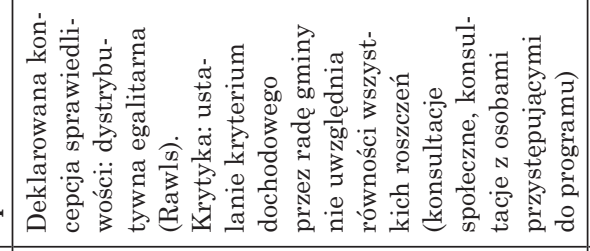 & 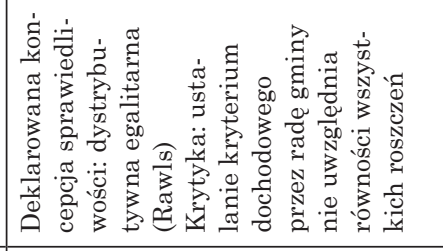 \\
\hline & 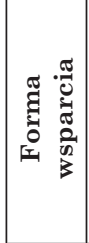 & 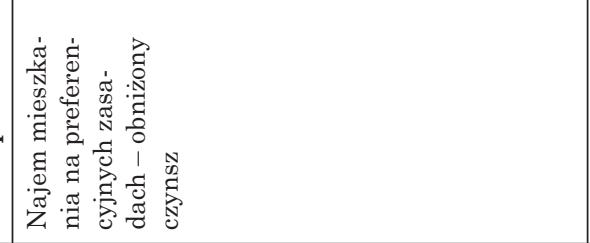 & 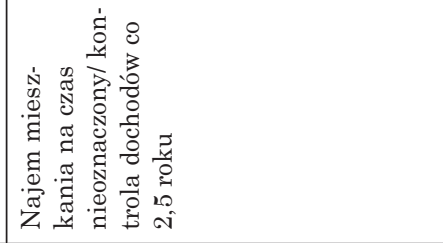 \\
\hline & 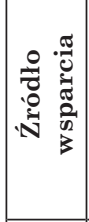 & 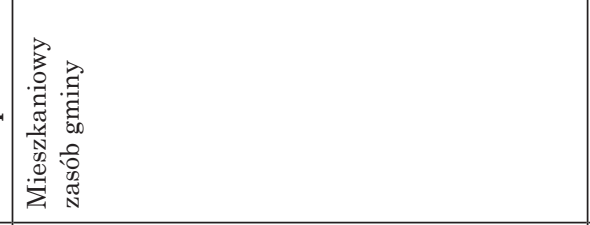 & 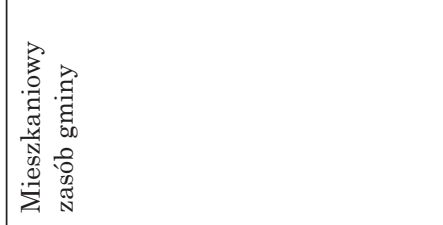 \\
\hline & 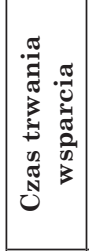 & 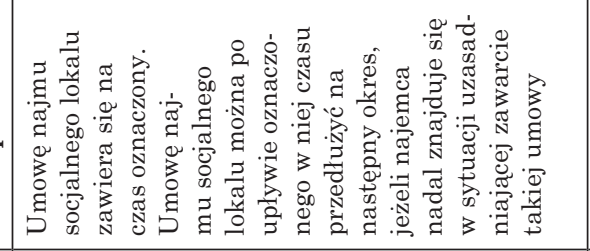 & 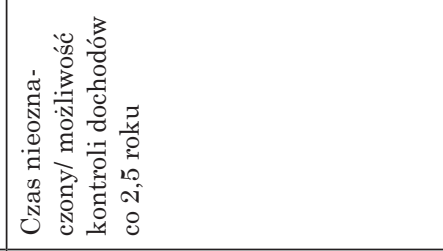 \\
\hline & 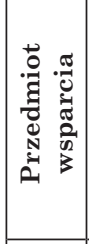 & 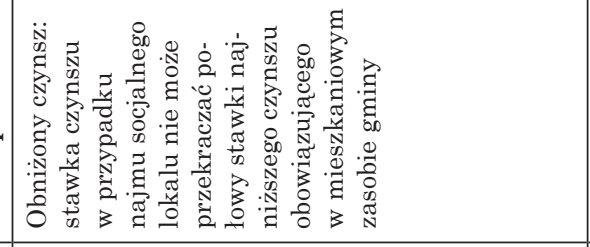 & 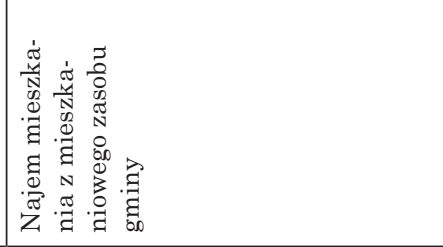 \\
\hline & 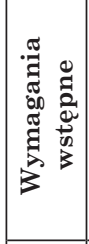 & 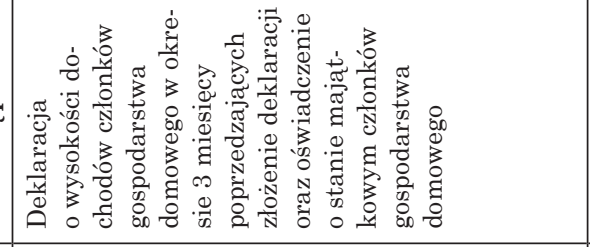 & 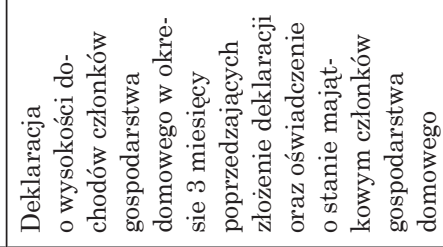 \\
\hline & 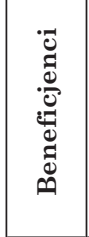 & 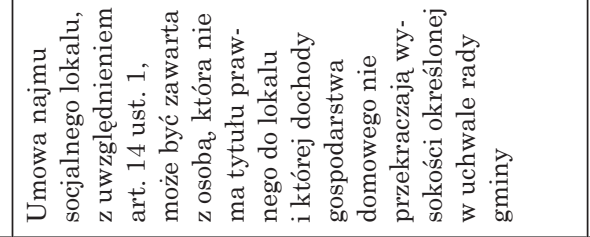 & 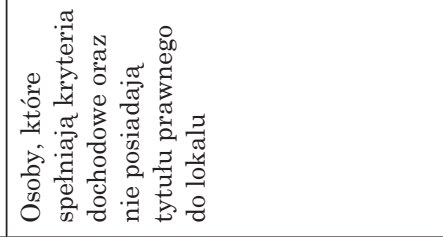 \\
\hline & 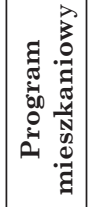 & 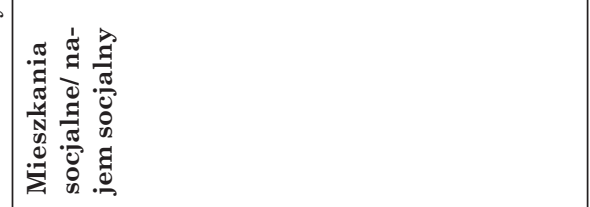 & 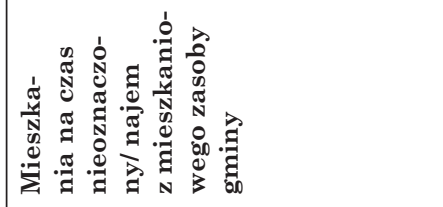 \\
\hline
\end{tabular}




\begin{tabular}{|c|c|}
\hline 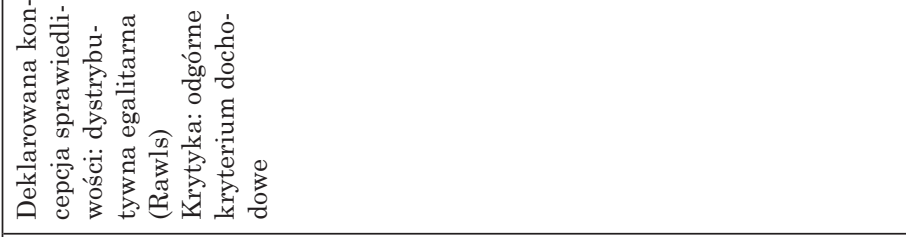 & 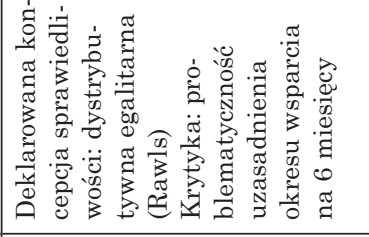 \\
\hline 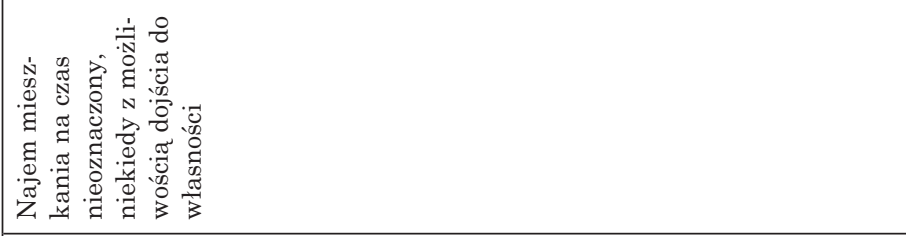 & 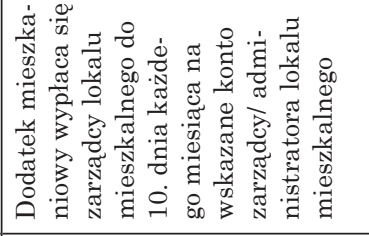 \\
\hline 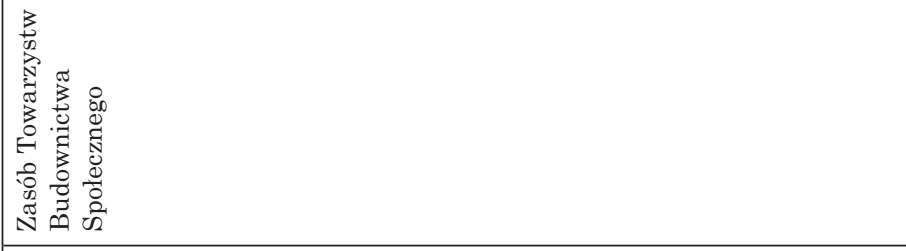 & 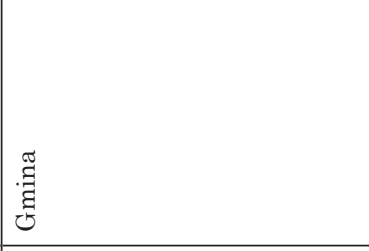 \\
\hline 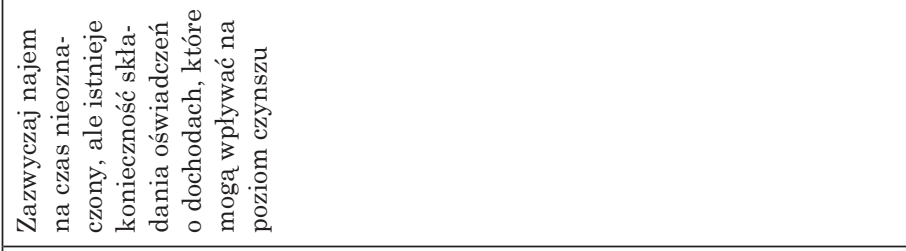 & 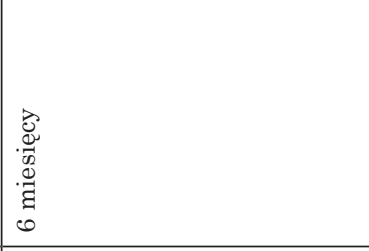 \\
\hline 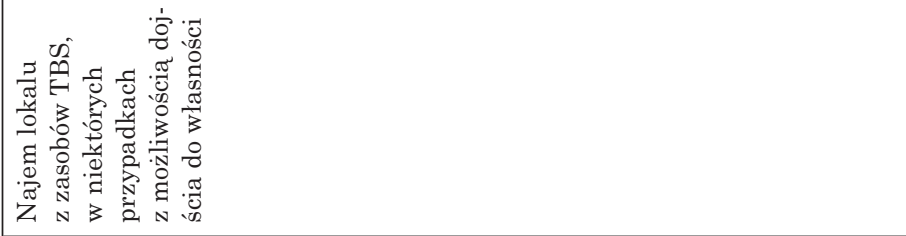 & 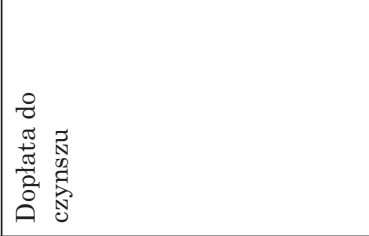 \\
\hline 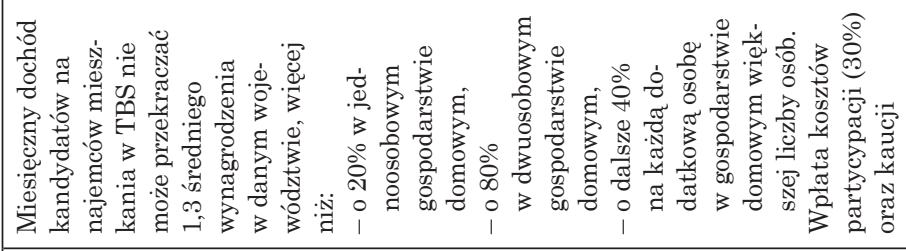 & 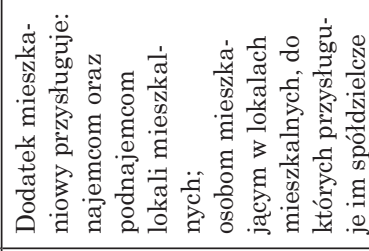 \\
\hline 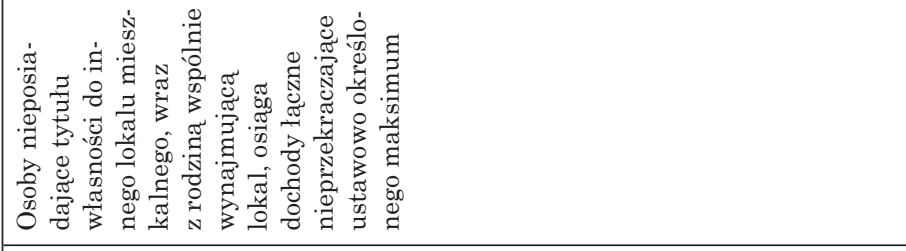 & 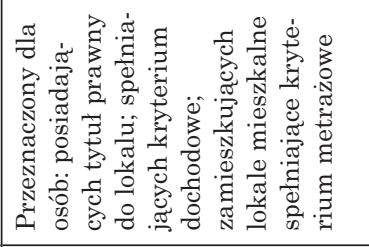 \\
\hline 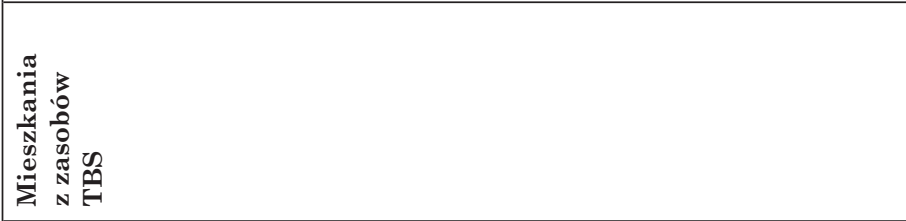 & 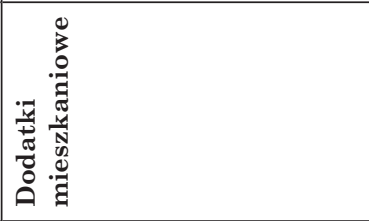 \\
\hline
\end{tabular}




\begin{tabular}{|c|c|}
\hline & 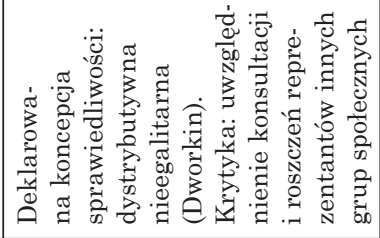 \\
\hline & 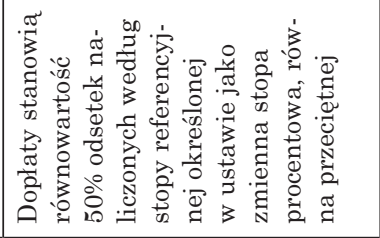 \\
\hline & 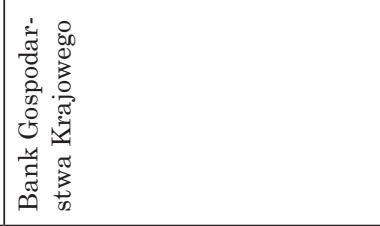 \\
\hline & 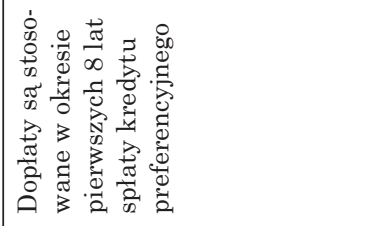 \\
\hline & 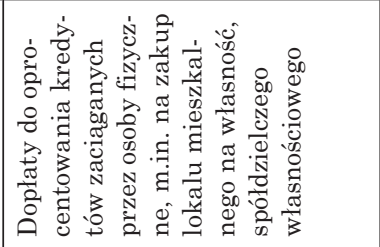 \\
\hline 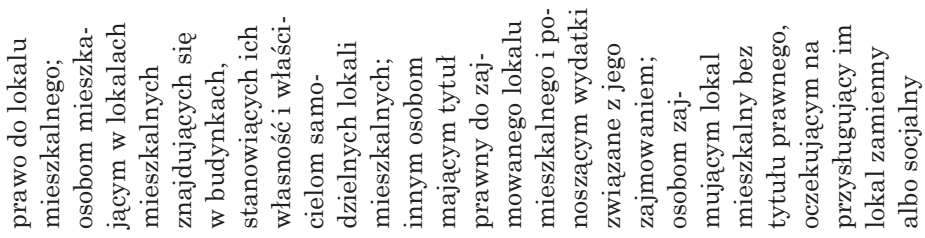 & 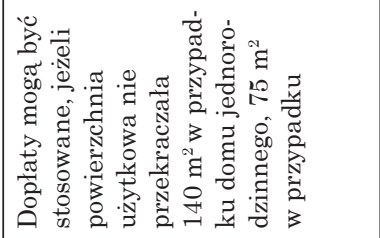 \\
\hline & 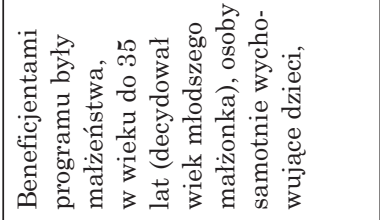 \\
\hline & 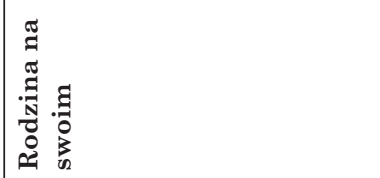 \\
\hline
\end{tabular}




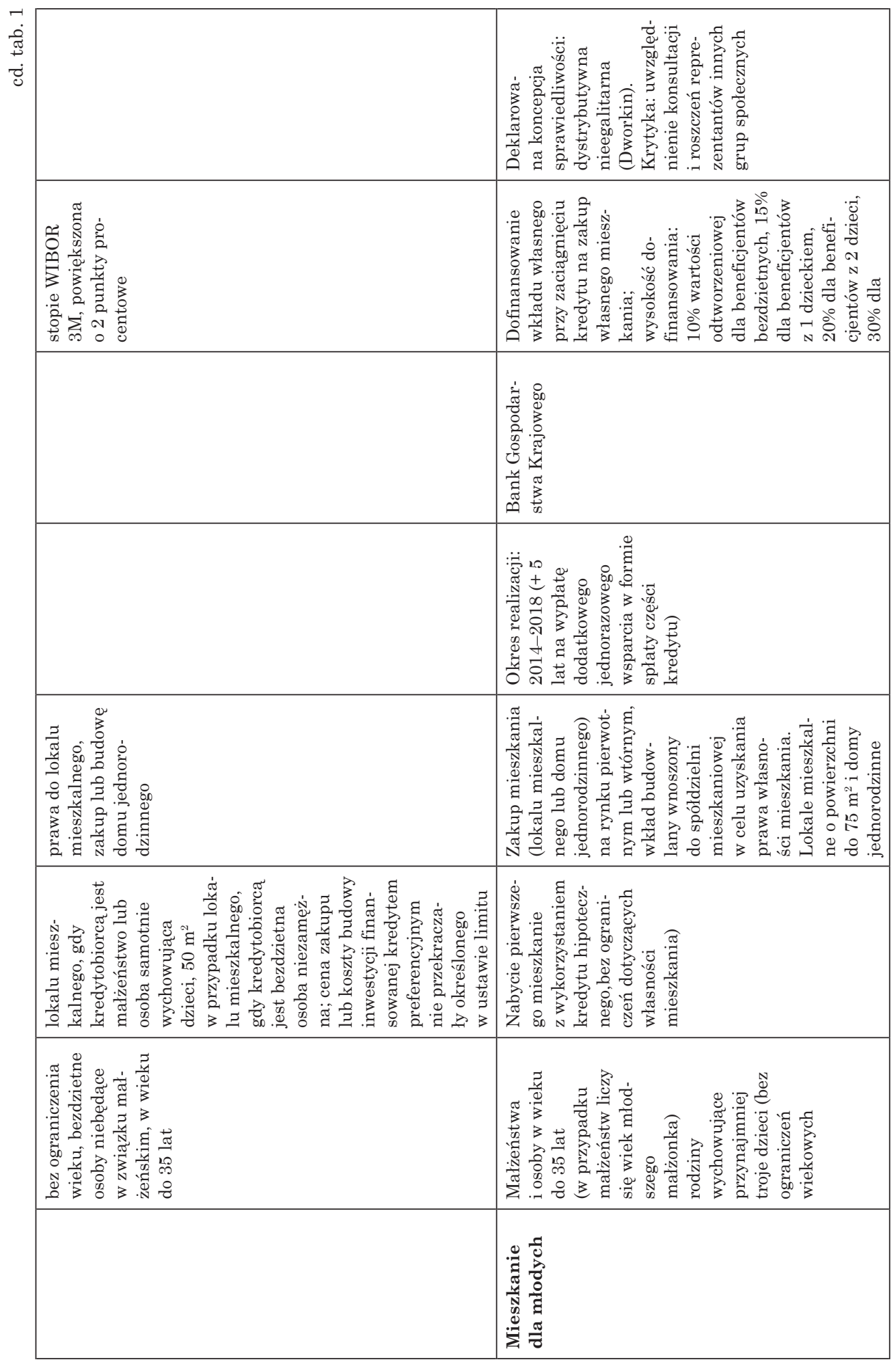




\begin{tabular}{|c|c|}
\hline & 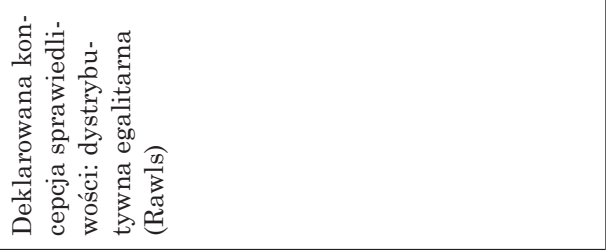 \\
\hline \multirow[t]{3}{*}{ 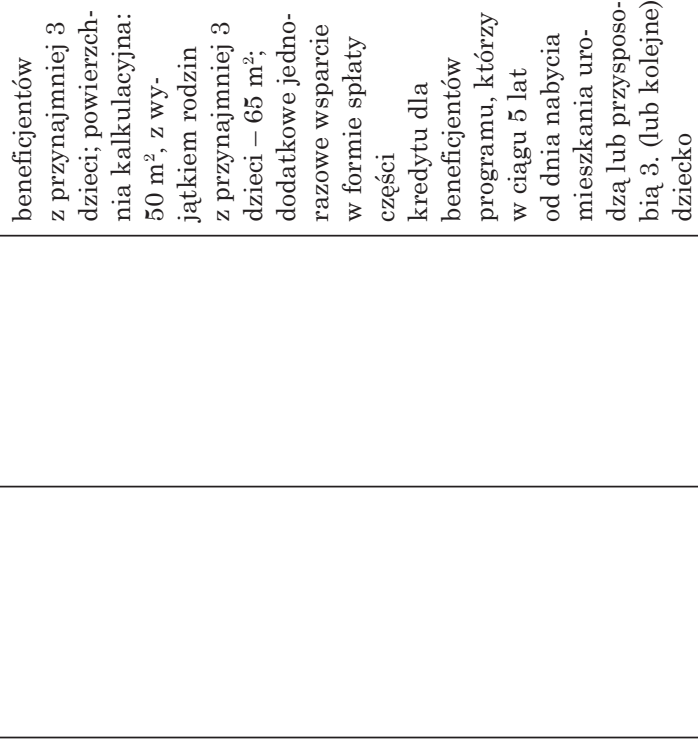 } & 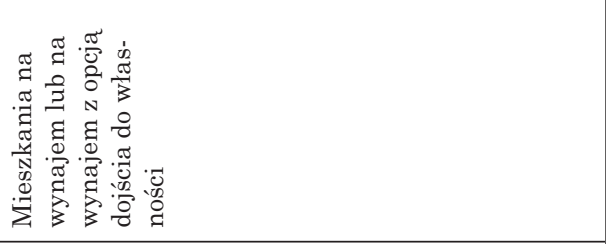 \\
\hline & 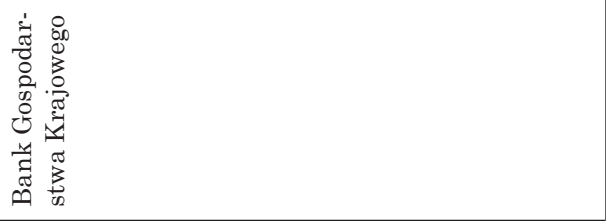 \\
\hline & 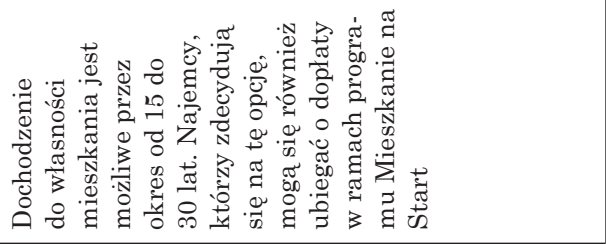 \\
\hline \multirow[t]{4}{*}{ 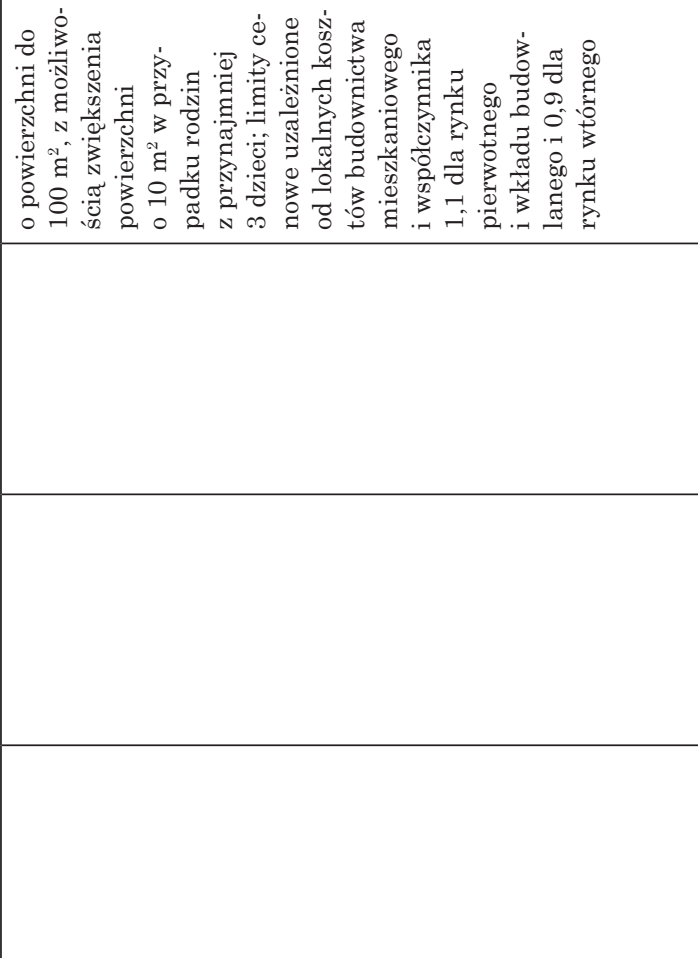 } & 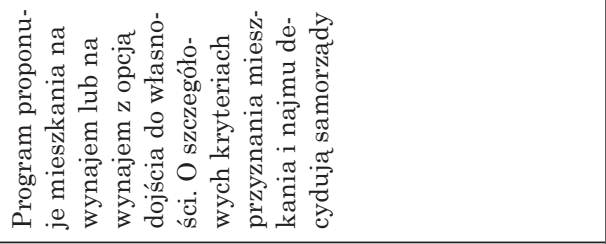 \\
\hline & 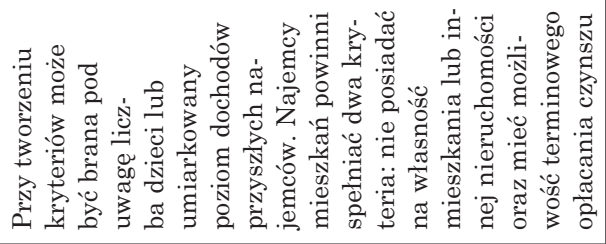 \\
\hline & 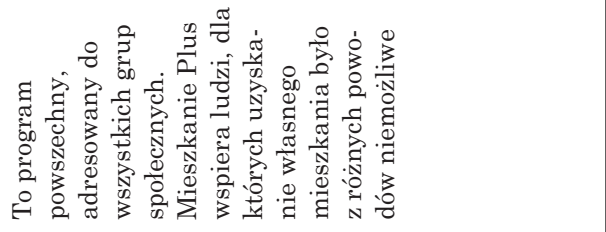 \\
\hline & 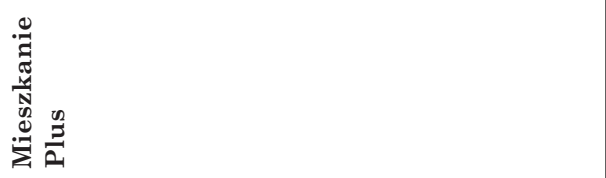 \\
\hline
\end{tabular}




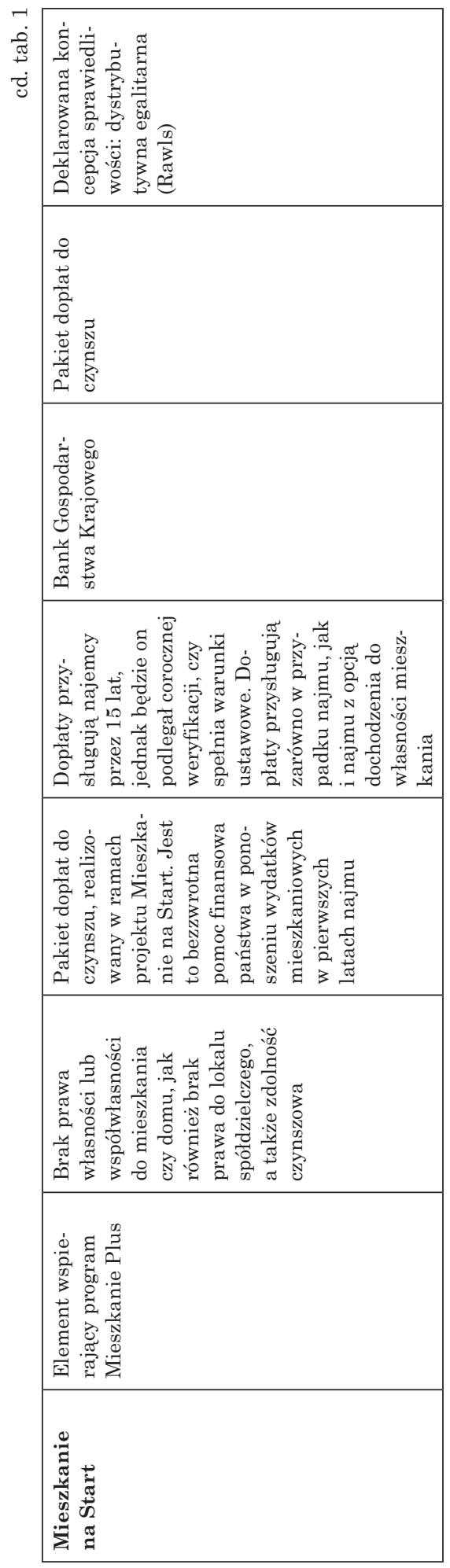




\section{PODSUMOWANIE}

Odpowiedź na pytania, czy pojęcie sprawiedliwości tkwi u podstaw ustalanych kryteriów, zasad polityki mieszkaniowej i jak to pojęcie jest na tym gruncie rozumiane i „umocowane”, wymagała „przyjrzenia się” poszczególnym programom mieszkaniowym. Jak widać z powyższego zestawienia, idea sprawiedliwości dystrybutywnej realizowana była - w swej warstwie aksjologiczno-deklaratywnej - w dwóch wersjach: egalitarnej i nieegalitarnej. Za każdym razem jednak głównymi kryteriami stosowanymi w tych programach sa kryteria dochodowe, ustalane albo przez samorządy, albo przez ustawodawcę. Brak uwzględnienia wszystkich roszczeń „stron” zainteresowanych jest stronniczy i narusza zasady sprawiedliwości społecznej zarówno w wersji Rawlsa, jak i Dworkina. „Umocowanie” idei sprawiedliwości społecznej w polityce mieszkaniowej jako kryterium oceny procedur związanych z dystrybucją zasobów mieszkaniowych zdaje się więc niewystarczające, ponieważ nie wiąże się z ,zasłoną niewiedzy" Rawlsa i Dworkina, z abstrahowaniem od określonej sytuacji społecznej i myśleniem, by wyrównywać szanse i nierówności tak, by były one z korzyścią dla wszystkich. W obecnej formule programów mieszkaniowych alokacja i redystrybucja zasobów mieszkaniowych narusza zasady sprawiedliwości społecznej, zasady ustrojowej, zapisanej w Konstytucji.

Aktualnie obok programów mieszkaniowych dla zamożnych (Rodzina na swoim i Mieszkanie dla młodych) i niezamożnych gospodarstw domowych pojawiają się również kierowane do gospodarstw, które z uwagi na swój status społeczno-ekonomiczny moga mieć problem z nabyciem mieszkania na zasadach rynkowych. Sa to rodziny młode, wielodzietne, nieposiadajace kapitału na zakup mieszkania z rynku bądź nieposiadajacce zdolności kredytowej. Jak wynika z przeprowadzonych rozważań, funkcjonujace w ostatnich latach programy mieszkaniowe skierowane były do gospodarstw albo ubogich lub średnio ubogich, albo zamożnych, mających zdolność kredytową lub środki umożliwiajace pokrycie kosztów partycypacji w zasobach TBS. Dopiero wprowadzony program Mieszkanie Plus wraz z jego elementem wspierającym, którym jest Mieszkanie na Start stało się - przynajmniej w warstwie legislacyjno-teoretycznej - krokiem przełomowym w kontekście podkreślanej w Konstytucji RP sprawiedliwości społecznej.

W opracowaniu starano się pokazać, że programy mieszkaniowe maja za zadanie wspierać obywateli w zaspokajaniu ich potrzeb mieszkaniowych i realizować zasady sprawiedliwości społecznej, jednakże w funkcjonujących dotychczas programach autorki dostrzegają pęknięcia, które powodują naruszenie zasad sprawiedliwości społecznej.

Karolina Nowak

Uniwersytet Ekonomiczny w Poznaniu

karolina.nowak@ue.poznan.pl

https: / /orcid.org/0000-0002-2091-8965

Zuzanna Rataj

Uniwersytet Ekonomiczny w Poznaniu

zuzanna.rataj@ue.poznan.pl

https: / /orcid.org/0000-0001-7442-0030 
Arystoteles (1996). Etyka nikomachejska. Tłum. D. Gromska. Warszawa: Wydawnictwo Naukowe PWN.

Bourke, V.J. (1970). Historia etyki. Tłum. A. Białek. Toruń: Wydawnictwo Krupski i S-ka.

Dworkin, R. (2000). Sovereign virtue. The Theory and Practice of Equality. Cambridge, MA: Harvard University Press.

Lis, P. (2012). Wahania cykliczne rynków mieszkaniowych. Toruń: Wydawnictwo Adam Marszałek.

Hume, D. (2005). Badania dotyczące zasad moralności. Tłum. M. Filipczuk, T. Tesznar. Kraków: Zielona Sowa.

Karalus, A. (2015). Kontrowersje wokół zagadnienia sprawiedliwości dystrybutywnej, Filo-Sofija, Z problemów współczesnej filozofii II, nr 29 (2015/2/II): 219-238.

Kopaliński, W. (2003). Słownik mitów i tradycji kultury. Warszawa: Oficyna Wydawnicza Rytm.

Marks, K. (1956). Kapitał. Krytyka ekonomii politycznej. Tłum. H. Lauer. Warszawa: Książka i Wiedza.

Rataj, Z. (2018). Społeczne budownictwo mieszkaniowe i jego rola w zaspokajaniu potrzeb mieszkaniowych niezamożnych gospodarstw domowych w Polsce. Warszawa: CeDeWu.

Rawls, J. (1994). Teoria sprawiedliwości. Tłum. M. Panufnik, J. Pasek, A. Romaniuk. Warszawa: Wydawnictwo Naukowe PWN.

Reale, G. (1997). Historia filozofii antycznej. Tom 2. Tłum. E.I. Zieliński. Lublin: Wydawnictwo KUL.

Rousseau, J.J. (1956). Trzy rozprawy z filozofii społecznej. Tłum. H. Elzenberg. Warszawa: PWN.

\title{
THE ALLOCATION AND REDISTRIBUTION OF HOUSING RESOURCES IN POLAND IN THE LIGHT OF THE CONCEPT OF SOCIAL JUSTICE (OF RAWLS AND DWORKIN)
}

\author{
$\mathrm{Su} \mathrm{m} \mathrm{m}$ a r y
}

The article concentrates on social justice in the context of housing allocation and redistribution in Poland, especially the stock of social housing. Consideration is given to the changes currently taking place, which are leading to an increase in social justice, understood in accordance with John Rawls' concept of distributive justice. The aim of the article is to answer the question of whether the concept of social justice (which is anchored in the Constitution of the Republic of Poland) has an impact on the implemented housing policy. If so, how is horizontal and vertical equity realised in the face of changes and reforms in housing programmes? The analysis of the concept of social justice in housing policy covers the period from 2006, when the programme supporting the purchase of the first flat 'Rodzina na swoim' was established, to 2019 and the programme 'Mieszkanie Plus.'

Keywords: housing policy; social justice; social housing; rental housing; municipality housing; axiology 